\title{
IN SEARCH OF DECISION-MAKING SITUATION (DMS) IN INTERNATIONAL RELATIONS: A REVIEW OF UNPACKED PARIS CLIMATE CHANGE AGREEMENT
}

\author{
Majid Asadnabizadeh \\ Uniwersytet Marii Curie-Skłodowskiej w Lublinie \\ Katedra Stosunków Międzynarodowych \\ ORCID ID: https://orcid.org/0000-0001-7331-3268 \\ e-mail: majid.asadnabizadeh@mail.umcs.pl
}

\begin{abstract}
The Paris Climate Agreement (PCA) of December 2015 marks a decisive point in international relations. The Paris Agreement (PA) established unpacked climate change pledges and policies which offer a significant situation to the international relations decision-making process. Therefore, this paper stands on the Decision-making Situation (DMS) in International relations to inform unpacked Paris climate change agreement.

The approach of this paper to the Decision-making Situation (DMS) embedded in the Paris climate change agreement focuses on review, identifying incentives, Decision-making Situation of the Paris agreement (DMS-PA), and EX- Political steps on the Paris Agreement (EXP-PA) model. The paper briefly assesses specific incentives: Copenhagen, Cancun, Durban, Doha, Warsaw, Lima to track review methods towards DMS related to PA. The review and analysis in this paper lay out a detailed process, techniques, and guidelines for the future framework of DMS in international climate change system (ICCS) analysis.
\end{abstract}

Keywords: Decision-making, International relations, Climate change, Paris agreement

\section{INTRODUCTION}

Climate change policy and situation of decision is a frustrating issue both for international relations and scientists who have investigated what is happening to the international system and specifically to the global climate change system. Scientific evidence about the seriousness of the problem continues to accumulate, but states have taken few effective decisions. However, at the 21 st Conference of Parties of the U.N. Framework Convention on Climate Change (UNFCCC), almost all the states agreed to a new Paris Agreement on Climate Change (2015) (Keohane and Oppenheimer, 2016). The author of this review proposes that the 
Paris climate change agreement marks a "Decision-making Situation (DMS)" in International relations that attempts to unlock failed understanding of the international climate change situation. The objective of this paper is to provide a preliminary and, therefore, a review of the political consensus obtained at the Paris agreement and the procedure under which the P.A. generated policies and actions that made a significant impact on international decision-making. Hence, the research's central question is how the Decision-making Situation of the Paris agreement (DMS-PA) has shaped? The author does believe that Decision-making Situation (DMS) in International relations and climate change issues can only be understandable and effective if we look at the situation of negotiations and behaviors of different actors. There are some incentives such as Copenhagen negotiations, The Cancun Summit, Durban, and Doha that have generated political interactions in which states play a leading role in shaping Decision-making Situation (DMS). Thus, the author will begin in section 2 by defining the methodology, in section 3 author will explore the key methodological framework on DMS-PA with a detailed model for further review and assessment of negotiations observed during the DMS. Section 4 of the paper is the Pace of political negotiations and conclusion which emphasizes on main points that create the Decision-making Situation of the Paris agreement (DMS-PA).

\section{A PATHWAY TO KNOWLEDGE: METHODOLOGY}

To answer the given research question, qualitative methods would be most appropriate to find an answer. Literature review on related topics suggests that qualitative methods are most appropriate (Badr \& Acitelli, 2005; Berg \& Upchurch, 2007). This method will aid the author in understanding the relationship of the Decision-making Situation in connection to the Paris agreement. This method will involve a non-random sampling strategy (NSS) to get a mixture of incentives observed for this study.

\subsection{Toolkit: 6 incentives of the methodology}

The six incentives are summarized in table 1. The author argues that, as a set, these six incentives provide a harmonized and interactive framework and a bunch of practical guidelines for a review and assessment in this study. Also, the author has fully developed this arena concerning qualitative research traditions. 
Table 1. 6 Incentives that drive the advancement of the methodology and review

\begin{tabular}{|c|c|c|}
\hline Domain & Incentives of P.A. & Description and review \\
\hline DMS & Copenhagen & DMS-PA \\
\hline DMS & Cancun & DMS-PA \\
\hline DMS & Durban & DMS-PA \\
\hline DMS & Doha & DMS-PA \\
\hline DMS & Warsaw & DMS-PA \\
\hline DMS & Lima & DMS-PA \\
\hline
\end{tabular}

Source: Author own-constructed

The author of this study has started to fully develop these domains (i.e., Decision-making Situation (DMS)) concerning mixed incentives, which reveals an emerging methodology for reviewing the Decision-making Situation of the Paris agreement (DMS-PA).

\section{DMS-PA FRAMEWORK}

As the author of this study in the previous section(methodology) has considered, there is a specific way that literature review shows itself throughout the Decision-making Situation of the Paris agreement and involves the use of one of the research traditions (i.e., qualitative). In this section, the author will review and analyze ways that literature represents a collection of data (i.e., 6 Incentives). Hence, methodology (section2) and incentives can be types of mechanisms and processes to bring it to fruition (i.e., DMS-PA). This would be a framework. There are many frameworks within the six- Incentives table, such as EX-Political steps on Paris Agreement. Therefore, EX- Political steps on Paris Agreement (EXP-PA) is a DMS-PA framework.

\subsection{Introducing the EXP-PA Model}

As the author has demonstrated in the previous sections, the review of this study involves DMS-PA. As the phrase suggests, the EXP-PA Model compromises 6 Political steps: 1: Copenhagen conference, 2: Cancun conference, 3: Durban, 4: Doha, 5: Warsaw, 6: Lima. These six political steps are multidimensional, interactive, dynamic, and synergistic. By multidimensional, the Author means that each of the steps has multiple components. By interactive, I mean that each step is dependent on all the other steps. By dynamic, the Author means that the EXP-PA is vibrant, energetic, lively, and eventful — and, hence, exciting. By synergistic, the Author means that the EXP-PA follows core principles for climate change synergistic approaches. 
Table 2. Model EXP-PA (as a framework) DMS-PA

\begin{tabular}{|c|c|c|c|c|}
\hline Domain & $\begin{array}{c}\text { Incentives } \\
\text { of P.A. }\end{array}$ & $\begin{array}{c}\text { Description } \\
\text { and review }\end{array}$ & DMS-PA framework & $\begin{array}{c}\text { Model } \\
\text { DMS-PA }\end{array}$ \\
\hline DMS & Copenhagen & DMS-PA & EX- Political steps on Paris Agreement(EXP-PA) & EXP-PAC \\
\hline DMS & Cancun & DMS-PA & EX- Political steps on Paris Agreement(EXP-PA) & EXP-PAC \\
\hline DMS & Durban & DMS-PA & EX- Political steps on Paris Agreement(EXP-PA) & EXP-PAD \\
\hline DMS & Doha & DMS-PA & EX- Political steps on Paris Agreement(EXP-PA) & EXP-PAD \\
\hline DMS & Warsaw & DMS-PA & EX- Political steps on Paris Agreement(EXP-PA) & EXP-PAW \\
\hline DMS & Lima & DMS-PA & EX- Political steps on Paris Agreement(EXP-PA) & EXP-PAL \\
\hline
\end{tabular}

Source: Author own-constructed

\section{USING EXP-PA FOR INTERPRETATION PHASE}

As seen in the table.2 (Model), the 6 incentives can be applied to all of the DMS-PA frameworks: EX-Political steps on Paris Agreement Copenhagen (EXPPAC), EX- Political steps on Paris Agreement Cancun (EXP-PAC), EX- Political steps on Paris Agreement Durban (EXP-PAD), EX- Political steps on Paris Agreement Doha (EXP-PAD), EX- Political steps on Paris Agreement Warsaw( EXPPAW), EX- Political steps on Paris Agreement Lima (EXP-PAL). The following section provides an overview of these incentives.

\subsection{Pace of political negotiations: Dealing with Consensus before the PA}

The Paris accord culminated in the U.N. climate change regime's different stages. One of the stages was the negotiation, implementation, and entry into force of the UNFCCC from 1990-1995. From 1995-2004, another occupied the decade from initiating talks on the Kyoto Protocol to its entry into force. Negotiations that eventually led to Paris started in 2005 when attention switched to what to do after 2012, after the first engagement period of the Kyoto Protocol finished. Developing nations pushed for a continuation of the Kyoto scheme. Still, Kyoto's target groups were unwilling to do so because they did not want to be bound by objectives while the United States, China, and other significant economies did not. Instead, they were in favor of a more worldwide strategy. The ultimate compromise was to undertake negotiations along two parallel lines, one to consider a Kyoto Protocol amendment creating a second engagement period, and the other to encourage "long-term collaborative action" under the UNFCCC. In 2005, the Kyoto Protocol parties initiated the first path; two years later, the UNFCCC parties introduced the second path in the Bali Action Plan. At the 2009 Copenhagen Conference, both tracks were to conclude their work. 


\subsubsection{The road of Copenhagen negotiations2009}

Copenhagen's U.N. Climate Change Conference was a historical occurrence in many respects. It defined the culmination of two years of intensive negotiations under the U.N. Framework Convention on Climate Change (UNFCCC) and the Bali Roadmap, agreed in December 2007 by the 13th Conference of the Parties (COP 13). Millions of individuals around the globe expected that Copenhagen would be a turning point in the fight against climate change. The high-level section brought together 115 Heads of State and Government and was commonly publicized as one of New York's biggest high-level gatherings. More than 40,000 individuals have applied for the Conference's accreditation, far surpassing the Conference venue's 15,000 ability (see, e.g., Dimitrov, 2010; Scott\&Becken, 2010). The Copenhagen Accord was instantly confronted with solid criticism in terms of substance. However, countries argued that included two ${ }^{\circ} \mathrm{C}$ goals and many other significant provisions in the contract. Its mitigation measures by advanced nations are commonly regarded as - obviously weak and - a step backward from the Kyoto Protocol. Developed countries are not committed to legally binding cuts in emissions. Likewise, there is no quantification of a worldwide long-term reduction target or particular peak timing for worldwide emissions. Instead, the arrangement indicates a bottom-up strategy by which advanced and developing nations submit their pledges to the Convention for data reasons, a technique most prominently advocated by the U.S. (International Institute for Sustainable Development, 2009). Judging from the high rhetoric heard before the Copenhagen gathering, urging parties to follow the Kyoto Protocol to conclude negotiations on a new international climate change agreement, the findings are seen as a failure. The Copenhagen Agreement, although it was a necessary consequence of the discussions, did not impose any meaningful and verifiable responsibilities, such as precise carbon goals or financial payments. However, this fact should not be allowed to undermine the significant progress made in at least three areas: funding, deforestation, and adaptation.

i. For the first time, developed countries are committing to jointly mobilizing $\$ 100$ billion from public and private sources annually by 2020 . This could not only disable the financial standoff, but it also gives further incentive to carbon market development. Furthermore, there is a collective commitment to provide "new and additional, consistent and sufficient funding" for the 2010-12 period of $\$ 30$ billion, with "balanced allocation between adaptation and mitigation" prioritizing adaptation funding for the most vulnerable developing countries.

ii. There is specific recognition for acting on deforestation and degradation of forests and for creating a mechanism, i.e., a body, to mobilize the required resources.

iii. Adaptation action and collaboration have been given ' urgent ' attention, especially in the least developed countries, small island developing coun- 
tries, and Africa, with developed countries committed to providing financial resources (Egenhofer \& Georgiev, 2009).

The agreement discusses all the key elements of the Bali Action Plan: a longterm objective; mitigation; technology; forests; and assessment, monitoring, and verification.

\section{Long-Term Goal}

The deal agrees that the global average temperature rise would be below 2 degrees Celsius. It also calls for a study of the agreement by 2015, involving the long-term goal of 1.5 degrees Celsius temperature increases.

\section{Mitigation}

Under the agreement, mitigation measures will be adopted by Annex I (developed) countries committing to adopt" economic-wide emission goals for 2020. Non-Annex I (developing) nations. (Least developed and small island nations "can take voluntary and support-based action"). Through January 31, 2010, developed state targets and a preliminary collection of actions through developing countries, including two footnotes. While not stipulated in the agreement, it is widely anticipated that the goals and actions entered will be compatible with those pushed in the run-up to Copenhagen by governments. Additional items by developing countries can be constantly attached to the appendix. Activities for which developing nations seek support are registering in a database, and those getting support will then be identified in the annex to the developing countries.

III. Measurement, Reporting, and Verification (MRV)

The emission objectives of Annex I states will be MRV'd "in compliance with current and any other requirements" from the COP and their allocation of financing to developing nations. Such principles are designed to ensure "solid, reliable and open" accounting of objectives and finances. Developing nations ' actions will "be responsive to their local" MRV, with the findings published in biennial national communications. The published data is subject to "external assessment and review under clearly articulated criteria to ensure compliance with national sovereignty." In compliance with recommendations established by the COP, developing country actions obtaining international support will be subject to international MRV (see, i.e., Niederberger \& Kimble, 2011).

IV. Forestry

The agreement announces the "immediate creation of a method ... to allow the deployment of financial resources from developed nations" to promote efforts to reduce deforestation and forest depletion emissions and increase forest sinks.

\section{Technology}

The treaty creates an innovation framework for both adjustment and mitigation to facilitate technology development and transition. Connection to UNFCCC and Kyoto - Two concurrent decisions under the Convention and the Protocol (see below) strengthen the two formal negotiation mechanisms before the agreement accepted Copenhagen. Nonetheless, these rulings do not refer to the accord. As a result, while certain parties are likely to scrutinize those negotiations to create 
and fully operationalize the agreement, no official reference has been made. In addition to that, The COP introduced the Ad Hoc Working Group on Long-Term Collective Action (AWG-LCA) in Bali two years ago as the venue to discuss the "agreed result" to accepting in Copenhagen. There was no completion of a set of decisions dealing with the critical elements of the Bali Action Plan and a significant decision connecting them. Whereas the parties have made significant advances in certain regions, some draft documents remain sidelined mainly. The COP approved a proposal to forward the text and expand the AWG-LCA's authority "to introduce the results of its work ... for acceptance" at COP 16 next year. A draft decision emerged when President Obama revealed that the tentative agreement defined next year's desired result as "a legally binding tool." Nevertheless, in the text given at the concluding plenary, the term did not show up. Some nations have called for reintegration, such as the United States, but others have rejected it, including India and Saudi Arabia ("COP 15 Copenhagen | Center for Climate and Energy Solutions", 2019).

\subsubsection{The Cancun Climate Summit}

The Cancun Summit began with the conviction that it would not be feasible to have a binding contract with considerably reduced expectations than the earlier Copenhagen conference. If the meeting's outcome were defining the circumstances, it describes as reasonably satisfying. The Cancun accord, which came close to unanimity (with only Bolivia voting against it), provides significant progress. In adapting to climate change, decreasing deforestation, and establishing economic aid for underdeveloped countries. The prominent positions were as follows:

i. The BASIC (Brazil, South Africa, India, and China) was blocked, with various nuance distinctions, but with a unified stance as its support for the negotiation process depended on contracts.

ii. The block of nations comprising Japan, Russia, Australia, and Canada were unwilling to support the second period of post-Kyoto emission reduction obligations unless the U.S. approved any possible agreement.

iii. Bolivia, Venezuela, Nicaragua, Ecuador, and Cuba's ALBA (Bolivarian Alliances for the Americas) block was critical of the entire process. It blocked the option of renewing the only binding decrease treaty across the summit.

iv. Developing nations with a clear stance of not presuming any reduction commitment until they set up their own for the post-Kyoto era.

v. Some particular positions, such as China's one, raised the chance that the voluntary goals arising from the Copenhagen Summit might be binding to assist the advancement of the negotiations (BC3 Public Policy Briefings, 2011).

Specifically, the agreements reached on December 11 in Cancun, Mexico, at the 2010 United Nations Climate Change Conference were significant steps. Forward 
in pursuing greenhouse gas emission reduction and assisting developing countries in protecting themselves against climate effects and creating a sustainable future. The primary goals of the Cancun Agreements are:

a) Establish clear objectives and a time timetable to reduce greenhouse gas emissions generated by humans over time to maintain the global average temperature increase below two degrees.

b) Encourage all nations to be involved in lowering these emissions in line with each country's distinct duties and capacities to do so.

c) Ensure international transparency of countries ' behavior and guarantee timely review of worldwide advancement towards the $2 \mathrm{C}$ objective.

d) Mobilize clean technology creation and transfer to increase initiatives to tackle climate change, get it to the correct location at the right moment, and have the most significant impact on both adaptation and mitigation.

e) In the brief and long term, mobilize and provide scaled-up resources to allow more effective action by developing nations.

f) Assist the world's particularly susceptible individuals in adapting through a coordinated adaptation strategy to the inevitable effects of climate change.

g) Building worldwide ability to fulfill the general challenge. Particularly in developing nations ("Intro to Cancun Agreements | UNFCCC," 2019).

\subsubsection{Durban 2011}

The talks have been going on mainly for several years: the Kyoto Protocol Ad Hoc Working Group (AWG-KP), initiated in 2005 to negotiate a second round of Kyoto emission objectives for developed countries. The Ad Hoc Working Group on Long-Term Cooperative Action (AWG-LCA) was introduced in 2007 to achieve a more comprehensive ' agreed result ' including the non-Kyoto United States and developed nations. Many expected the two tracks to culminate in a binding agreement at the 2009 Copenhagen Summit, which world leaders would attend. Instead, the Copenhagen Accord was reached, a political accord not legally accepted by the Conference of the Parties (COP). The Cancún Accords officially integrated the vital components of the Copenhagen Accord into the UNFCCC system the following year, including the mitigation pledges of nations, and took some initial steps to enforce them. Moreover, Cancún skirted broader legal problems, including Kyoto's destiny. The AWG-KP and the AWG-LCA are charging with pursuing their jobs across Durban (Center for Climate and Energy Solutions, 2011). The U.N. Climate Change Conference opened on Monday morning, November 28, 2011, in Durban, South Africa. Regarding a welcome ceremony attended by South African President Jacob Zuma and other senior officials, delegates collected for COP, CMP, SBI, and SBSTA opening plenary sessions. Christiana Figueres, UNFCCC Executive Secretary, stressed the need for two key actions in Durban: completing COP 16 duties and resolving the major political problems 
raised in Cancun. She emphasized the launch of the Adaptation Committee, the operationalization of the Technology Mechanism in 2012, the approval of the Green Climate Fund (GCF), and the clarification of fast-start financing. More than 12,480 people attended the conference, including over 5,400 government leaders, 5,800 UN agency and agency representatives, intergovernmental and civil society groups, and more than 1,200 journalists. During the Group of 77 and China (G-77/China), Argentina endorsed a second commitment term under the Kyoto Protocol as part of Durban's balanced and complete result, stating that states should ultimately operationalize the Cancun Agreements. Australia endorsed a shift to a climate change structure for the Umbrella Group, including all major economies, considering the nations' corresponding capacities. By 2015, Durban shall tackle the gap in ambition level, a single worldwide accounting system, and a mechanism for building a new comprehensive, legally binding global framework, according to the European Union (E.U.) (see, e.g., Kulovesi, 2012; Moncel, 2012). Switzerland described three significant measures for Durban for the Environmental Integrity Group (EIG): agreeing on critical components of the post-2012 international regime; Starting a process to enhance the mid-term system further; and agreeing on essential elements of a shared vision, including a longterm worldwide emission reduction target and a worldwide emission peak date. In brief, all countries in Durban committed to a detailed strategy that would come closer over time to achieve the ultimate goal of the Climate Change Convention: to stabilize atmospheric levels of greenhouse gasses at a point that prevents our hazardous interference with the climate system while preserving the right to sustainable development ("Summary and Analysis of the Durban Climate Change Conference, 28 November - 9 December 2011, Durban, South Africa", 2011). The Durban result was efficiently a political dedication by Europe and many other developed nations (which together account for about $15 \%$ of global emissions) to legally regularize a second commitment period at next year's gathering. The committees came up with solutions for addressing technical obstacles in turning commitments made under the Copenhagen and Cancún accords into enforceable emission targets for the E.U. and countries. The decisions:

I. Proclaim certain groups ' "purpose" to turn their undertakings into validated emission reduction and mitigation targets (QELROs) in an amendment to the CMP 8 Protocol.

II. Review emissions and deletions accounting standards for land-use, landuse alter, and forestry (LULUCF).

III.Authorize the ongoing use within the second dedication era of emissions trading and project-based systems (Clean Development Mechanism and Joint Implementation).

IV. Add nitrogen trifluoride (NF3), a fuel used to manufacture silicon wafers and other materials, to the Protocol's gas basket.

The formal introduction of the Green Climate Fund in favor of reduction and adaptation in developing nations was a significant outcome in Durban. Nevertheless, 
the decision does not indicate when developed countries manage to start making contributions to the project. The development is assigned to a 40 -member transitional Panel, which crafted a governance mechanism but failed to reach a complete agreement, mainly due to U.S. concerns. With a cover judgment resolving significant issues, the COP authorized the governing instrument. In Cancún, the countries agreed that the GCF would work independently under the COP's "supervision," not under the specific "power." The legislative framework allows for: a 24-member board of equal representation from developed nations and developing countries; a "fully independent" secretariat; eligible governments can receive donations directly, not through a multilateral agency like the United Nations. Environment Program; and a "facility" to support the operations of the private sector. The significant issues accepted in Durban included the interim secretariat (to be jointly run by UNFCCC and the Global Environment Facility) and the method for classifying a permanent host nation (to be appointed by the board and supported by the COP). The regulatory instrument notes that the program must "obtain" investments from developed nations and "may also obtain" funds from a "variety of other sources." The U.S. wanted to open it more specifically to investments from developing countries, a question implicitly raised by language that embraces the start-up fund proposal from South Korea. The COP on other financial matters:

i. COP Developed an Executive Committee to examine climate finance flows and provide direction and collaboration amongst the various UNFCCC funds to the COP.

ii. A work program initiates to examine possible long-term funding options that the U.S. had opposed, claiming that the UNFCCC was not the correct forum.

Many other measures to enforce the Cancún Agreements decided by the Parties such as:

a) Decisions on the composition and activities of a 16-member Adaptation Committee will serve as the Conference of Parties' "national consultative institution" on adaptation issues.

b) Decisions targeted choosing and operating a host nation for a new Climate Technology Center and Network in 2012.

c) Ongoing workshops to explain developed nations ' 2020 emission goals and "further appreciation of the range of mitigation acts" taken by developing countries.

d) Creating a web-based database where developing countries may indicate planned action steps that require help and developed countries can offer information on relevant assistance.

e) A decision to allow "effective market-based strategies" to be established to support measures by developing countries to minimize deforestation and land degradation emissions.

f) A judgment under the Treaty to create a new market-based strategy to help developed nations meet their emission objectives. 
Groups were unable to make progress on some other issues and postponed them to the year, which is as follows:

- A greenhouse gas emissions reduction aim by 2050 and a global emission limit.

- Continue to define the context and methods of a study of the 2-degree objective in 2013-15 and development towards it (The Center for Climate and Energy Solutions, 2011).

\subsubsection{Doha Climate Change Conference 2012}

The Climate Change Conference of the United Nations in Doha, Qatar, was held from November 26 to December 8, 2012. It included the 18th Conference of the Parties (COP 18) to the United Nations Framework Convention on Climate Change (UNFCCC) and the 8th Conference of the Parties to the Kyoto Protocol (CMP 8) assembly. Five subsidiary bodies also convened: the Subsidiary Implementing Body (SBI), the Subsidiary Scientific and Technological Advisory Body (SBSTA), the Ad Hoc Working Group on Annex I of the Kyoto Protocol (AWG-KP), the Ad Hoc Working Group on Long-Term Cooperative Action under the Convention (AWGLCA) and the Ad Hoc Working Group on the Durban Platform for Enhanced Action (ADP). The meeting attracted roughly 9,000 attendees, including 4,356 public officials, 3,956 representatives of U.N. bodies and agencies, intergovernmental organizations and civil society organizations, and 683 members of the press for the first moment that U.N. climate change negotiations took place in the Middle East. The Doha negotiations concentrated on ensuring that the contracts reached past meetings implemented by parties. The main goals of the Doha negotiations were to follow the Kyoto Protocol's 2nd commitment era and achieve the AWG-KP's work; complete the AWG-LCA's work, and advance the ADP negotiations (see, e.g., Campbell, 2013; Lal Pandey, 2014). The main issues were how to fill the gap between mitigation commitments and what is needed to accomplish the $20 \mathrm{C}$ target, considering the trim level of ambition that advanced nations have articulated so far, and how to ensure appropriate funding - securing economic flows by 2020 following the 2012 fast-track funding expiry and the 2020 long-term funding target. The COP agrees in its resolution (FCCC / CP/2012/L.16) to prolong the long-term financing work program for one year. The COP allows the Chairman of the COP to designate two co-chairs for the work program from a developing and established country party. It also intends to pursue the current Convention procedures for evaluating and updating the financial power needs of developing nations, including defining alternatives for mobilizing these tools and their adequacy, consistency, stability, and availability (Earth Negotiations Bulletin, 2012).

The "Doha Climate Gateway" was the result of two weeks of complex negotiations, the elements of which were as follows:

i. Restrictions introduced in which countries for the period 2013-2020 could use market mechanisms under the K.P. Just those states that are KP2 sig- 
natories can issue and use CDM and J.I. (market mechanisms under K.P.) credits and internationally shift these units.

ii. We use any surplus of Assigned Amount Units (AAUs) - units assigned under the K.P.'s First Commitment Period to all developed countries, including Russia and Ukraine. A massive surplus - will be minimal for the 2013-2020 period for national enforcement reasons and will vanish in the post-2020 period.

iii. Doha did not reach an ultimate decision on how to channel and spend billions of dollars in initiatives on reducing carbon emissions by preventing deforestation and rainforest degradation known as REDD.

iv. By the end of 2013, under the UNFCCC, new market mechanisms will be developing for use with obligations under all three procedures outlined above, such as sector linking and trading, REDD + . Simultaneously, states will establish a system to recognize new market tactics developed in the United States for worldwide compliance. This system anticipates providing extra incentives in nations like China, Korea, Colombia, and Mexico. To begin emissions trading systems in distinct models. The UNFCCC's role in showing acceptance of national organizations and their units after global commitments was purposefully left unclear in the text. A significant evaluation of the CDM will occur during 2013, including implementing the new global climate change architecture.

v. The K.P. text also offers a 2014 assessment of the level of commitment for developed countries in reducing objectives. This text is difficult to reconcile with a simultaneous debate on all nations' aims that will take place in 2015 to reach an agreement under the ADP.

vi. The debate on the Green Climate Fund (FCCC / CP/2012/L.17) endorsed its headquarters in the Republic of Korea. It also supported the job program of the Board, which involves developing the Private Sector Facility in 2013, mobilizing resources, setting up an independent Secretariat.

In its Executive committee decision (FCCC / CP/2012/L.16), the COP:

- Countries consider embracing the operationalization and development of the Central Committee.

- Endorse the Standing Committee's support program for 2013-2015

- Welcomes the work of the Standing Committee forum and invites the Standing Committee to promote the involvement of the personal, economic, and academic sectors in the forum

- Embraces the Standing Committee's new structure and working arrangements

- Determines that the Chair and Vice-Chair of the Standing Committee shall serve as co-chairs of the Standing Committee effective from its first session in 2013

- Chooses to reappoint the Committee as the Standing Budget committee 
- Requests the Committee to find ways to strengthen techniques for focusing on climate finance in preparing the first biennial evaluation and analysis of financial movements (Marcu, 2012).

\subsubsection{United Nations Framework Convention on Climate Change (COP 19)}

The conference on climate change in Warsaw took place in Poland from 11-23 November 2013. This conference included the 19th Conference of the Parties (COP 19) to the United Nations Framework Convention on Climate Change (UNFCCC) and the 9th Conference of the Parties to the Kyoto Protocol (CMP 9) meeting. The 39th session of the Subsidiary Body for Scientific and Technological Advice (SBSTA 39) and the Subsidiary Body for Implementation (SBI 39), as well as the third meeting of the Durban Platform for Enhanced Action Ad Hoc Working Group (ADP 2), were held during the summit. The conference attracted more than 8,300 attendees, including 4,022 public officials, 3,695 UN agency and agency representatives, intergovernmental and civil society organizations, and 658 press representatives. In Warsaw, negotiations concentrated on implementing contracts reached at past conferences, including promoting the job of the Durban Platform for Enhanced Action Ad Hoc Working Group (International Institute for Sustainable Development, 2013). Many viewed COP19 as a warm-up event for the big conference in Paris in 2015. At the 2015 session, both sides will have to agree to new responsibilities rounds for the third Kyoto era, which begins in 2020. This era implied that the Warsaw conference did not carry any meetings ' very high expectations in the past - especially Bali or Copenhagen. If anything, the disparities between developing and developed nations were wider. Negotiations between the 'Sides' have to extend and be fractious, often lasting until early. The key debates centered on the text for nations to table their next round of goals spanning the planned 2015 timeline (Hampton, 2014).

Here are some results outlined in four main fields of negotiation:

I. Financial Contributions

Finance and monetary contributions have been a critical component of the latest negotiations. Developing nations call for economic contributions to current financing systems before discussing measures to reduce emissions after 2020. Several fragmented pledges arose from Warsaw for fresh cash. As part of a significant new $\$ 280$ million financing initiative, the U.S. promised $\$ 25$ million to slow desertification and curb its impact on global carbon emissions. Countries also pledged $\$ 100$ million to complement the current Adaptation Fund established in 2008 to provide cash for poorer nations to adjust to climate change effects. New pledges of assistance were given to the Adaptation Fund by mainly European countries: Norway pledged \$2.5 million; Sweden promised \$30.2 million; Belgium pledged $\$ 1.6$ million, and Germany pledged $\$ 40.7$ million (or $€ 30$ million) (see, e.g., Bracking, 2014; Fridahl \& Linnér, 2015; Cui \& Gui, 2015). 


\section{Loss and Damage}

The new "Warsaw International Loss and Damage Mechanism Associated with Climate Change Impacts" does not promise liability for harm in developing nations induced by climate change effects, a red line for the United States and other developed countries. The mechanism positions the problem under an adaptation structure for at least three years, with a built-in review for 2016. This result reflected a hard-fought compromise between the U.S., Nicaragua, the Bahamas, and Fiji and was seen by both sides as a satisfying provisional result.

III.REDD+

Negotiators achieved several objectives at the 2010 Cancun conference, agreeing on important texts on science and technical regulations, funding, and a domestic cooperation system. Additions to the text on technical problems included choices to implement the protection of the environment and human rights in REDD+ initiatives, laying the groundwork for a scheme for tracking, reporting, and verifying. The reduction of carbon emissions from standing trees; establishing national forest surveillance schemes; establishing baselines or reference levels on which a nation measure attempts to reduce deforestation. Negotiating, the team also decided on the REDD+ finance document, including a provision that states need to demonstrate the latest evidence that safeguards are respected to compensate (Hultman \& Langley, 2013).

Ironically, in some cases, settlements seemed to be made so that members could announce some improvement. However, the prominent NGO has orchestrated a 'walk-out,' arguing that developing nations are too obstructionist in the last couple of days. Mr. Justin Lee, ambassador for the climate and a career officer in the Department of Foreign Affairs, led the Australian negotiation team. The Australian government's decision not to send a minister to the discussions caused widespread misunderstanding that Australia had abandoned climate change initiatives. Also, the Abbott government has reiterated that our national goal is 5 percent underneath the rate of 2000 emissions and that it will use the $\$ 1$ trillion 'Direct Action' plan to guarantee that the target is achieved (Hampton, 2014).

\subsubsection{COP 20}

The Lima Conference on Climate Change was held in Lima, Peru, from 1-14 December 2014. It included the 20th Conference of the Parties (COP 20) to the United Nations Framework Convention on Climate Change (UNFCCC) and the 10th Conference of the Parties to the Kyoto Protocol (CMP 10) session (see .i.e. Shockley \& Boran, 2015; Tschakert, 2015). Three subsidiary bodies (S.B.s) also met: the 41st sessions of the Subsidiary Body for Scientific and Technological Advice (SBSTA 41) and the Subsidiary Body for Implementation (SBI 41), and 
the 7th part of the second session of the Durban Platform for Enhanced Action Ad Hoc Working Group (ADP 2-7). The Lima Climate Change Conference gathered more than 11,000 attendees, including about 6,300 public officials, 4,000 UN agency and agency representatives, intergovernmental organizations and civil society organizations, and 900 media members. Negotiations in Lima concentrated on the results of the ADP needed to advance towards a contract at COP 21 in 2015 in Paris, such as the preparation of the data and system required to submit intended nationally determined contributions (INDCs) as early as possible in 2015 and progress on the elements of a draft negotiating text. Regarding long talks on a draft decision to advance the Durban Framework for Enhanced Action, COP 20 adopted the 'Lima Call for Climate Action,' which launches the negotiations for a 2015 agreement in the coming year, the process for submitting and reviewing INDCs and improving the ambition of pre-2020(Earth Negotiations Bulletin, 2014). Five main problems of the Lima Call for Climate Action, worth pursuing during the 2015 Paris Road:

a) An agreement has been reached for the first time in which all nations, if they are prepared, will define their targets and send their $\mathrm{CO} 2$ emission data by March 2015 (Intended Nationally Determined Contributions).

b) The Prevalent but Differentiated Responsibilities (CBDR) was a contentious problem that impacted negotiations among advanced and developing nations. COP20 could not describe how to distribute emission cuts among nations. At COP21 in Paris, this problem is discussed.

c) The arrangement reached is consistent with the job begun in Durban at COP17. Lima's focus was more global, with little mention of specific country progress. Unlike the Kyoto Protocol, which mainly covered advanced nations, this is a comprehensive agreement that extends to all countries.

d) Green Climate Fund funding slightly surpassed the target, reaching $\$ 10.2$ billion. The fund will allow developing nations to use a variety of climate change techniques. In 2015, a Private Sector Facility was established to ensure that private sector businesses may be authorized and have access to the fund.

e) They were implementing a fresh Measurement, Investigating, and Identification Framework. The first Multilateral Evaluation took place in Lima, offering higher accountability for advanced countries ' actions as they can compare their level of compliance with emission reduction objectives ("5 key outcomes of the Lima Climate Change Conference (COP20) | Sustainability for all", 2015).

In terms of INDCs, developed nations decided to focus only on mitigation on "nationally agreed obligations," although many developing countries still called for adjustment and financing. The agreement does not set out the context of INDCs directly. Through connecting INDCs to the end goal of the Treaty (stabilization levels of greenhouse gases to prevent dangerous anthropogenic interference with the climate system), the decision sets expectations for reduction contributions 
from all. It also encourages participants to "consider such as an element of adaptation." To measure the parties' commitments, the decision defines some data that the sides may provide, as necessary, including "quantifiable details" on the duration, range, and coverage of an INDC and the assumptions and methodologies used to measure and account for pollution. It also allows participants to specify how "reasonable and constructive" their commitments are.

Moreover, language saying "both parties should" include upfront data has been substituted by "can" in the final text, making this optional ante Consideration was also a topic of discussion at this meeting. Some parties have asked for various procedures to probe each other's anticipated pre-Paris commitments; big developing countries are attempting to block them. The ultimate decision dropped a mid-year "dialog" on the INDCs. Still, added guidance to the UNFCCC council in preparing a November analysis study on the INDCs' "cumulative impact" - in other words, how they compare with the reductions required to limit warming to $2^{\circ} \mathrm{C}$ based on differentiation. Throughout the decision, which industrialized countries roundly rejected, major developing nations pressed for a clear distinction between Annex I (developed) and non-Annex I (developing) states. The agreement uses the same language as the United States and China's most recent joint declaration, reiterating the UNFCCC idea of "shared but differentiated obligations and separate capacities," with the addition of "given different country conditions." Differentiation was also a matter for developing economies in the policy call for increased funding. Instead of taking the full responsibility itself, developed nations called for words to suggest that other actors should also participate "in a position to do so." The final document clearly "realizes other parties ' aid" (Center for Climate and Energy Solutions, 2014).

\section{CONCLUSION}

In closing, the Paris Agreement is an accomplishment than part of an ongoing and unpacked process. It opens the door to progress on climate change governance but does not assure it. For the situation of decision, there have been clear substantial steps with components that can be monitored. The author has emphasized the importance of political consensus in affecting the Decision-making Situation (DMS) in International relations on the Paris agreement. In the area of climate change decision making, the EX- Political steps on Paris Agreement (EXP-PA) is closely linked to DMS. DMS is playing an important role in mobilizing incentives of P.A. for understanding the Decision-making Situation of the Paris agreement (DMS-PA). Review and assessment of the DMS-PA are the most important criteria not when simply pointing to the international climate change system, but when researchers are mobilizing DMS-PA for EXP-PA actions. For the Paris agreement to put a review on a path assessment toward Decision-making Situation, need to pay necessary attention to the political Consensus before the PA. 
Tytul: W poszukiwaniu sytuacji decyzyjnej (DMS) w stosunkach międzynarodowych: Przegląd nierozpakowanego porozumienia klimatycznego z Paryża

Streszczenie: Porozumienie klimatyczne z Paryża (PCA) z grudnia 2015 r. wyznacza decydujący punkt w stosunkach międzynarodowych. Porozumienie paryskie (PA) ustanowiło otwarte zobowiązania i polityki dotyczące zmian klimatycznych, które oferują istotną sytuację w procesie podejmowania decyzji w stosunkach międzynarodowych. Dlatego niniejszy dokument dotyczy sytuacji decyzyjnej (DMS) w stosunkach międzynarodowych, aby poinformować o porozumieniu klimatycznym z Paryża.

Podejście tego dokumentu do sytuacji decyzyjnej (DMS) zawartej w porozumieniu paryskim w sprawie zmiany klimatu koncentruje się na przeglądzie, określeniu zachęt, sytuacji decyzyjnej porozumienia paryskiego (DMS-PA) oraz EX- kroki polityczne w sprawie porozumienia paryskiego (EXP). -PA) model. Artykuł krótko ocenia konkretne zachęty: Kopenhaga, Cancun, Durban, Doha, Warszawa, Lima w celu śledzenia metody przeglądu w kierunku DMS związanego z PA. Przegląd $\mathrm{i}$ analiza $\mathrm{w}$ tym artykule przedstawiają szczegółowy proces, techniki i wytyczne dla przyszłych ram DMS w analizie międzynarodowego systemu zmian klimatu (ICCS).

Słowa kluczowe: Podejmowanie decyzji, Stosunki międzynarodowe, Zmiana klimatu, Porozumienie paryskie

\section{REFERENCES}

1. Badr, H., \& Acitelli, L. K., (2005). Dyadic adjustment in chronic illness: Does relationship talk matter? Journal of Family Psychology. 19(3), 465-469. doi: 10.1037/0893-3200.19.3.465

2. Berg, C. A., \& Upchurch, R., (2007). A developmental-contextual model of couples coping with chronic illness across the adult lifespan. Psychological Bulletin. 133(6), 920-954.

3. BC3 PUBLIC POLICY BRIEFINGS. (2011). the Cancun Climate Summit: a Moderate Success. Bilbao, Spain. Retrieved from http://www.bc3research.org/lits_publications.html.

4. Bracking, s. (2014). The Anti-Politics of Climate Finance: The Creation and Performativity of the Green Climate Fund. Antipode, 47(2), 281-302. https://doi.org/10.1111/anti.12123.

5. COP 15 Copenhagen | Center for Climate and Energy Solutions. (2019). Retrieved 23 October 2019, from https://www.c2es.org/content/cop-15-copenhagen/.

6. Campbell, D. (2013). After Doha: What Has Climate Change Policy Accomplished? Journal of Environmental Law, 25(1), 125-136. https://doi.org/10.1093/jel/eqt001.

7. Cui, L., \& Gui, H. (2015). Sharing the burden of financing the green climate fund in the Post-Kyoto era. International Journal of Climate Change Strategies and Management, 7(2), 206-221. https://doi.org/10.1108/ijccsm-11-2013-0125.

8. Dimitrov, R. (2010). Inside UN Climate Change Negotiations: The Copenhagen Conference. Review of Policy Research, 27(6), 795-821. https://doi.org/10.1111/j.1541-1338.2010.00472.x.

9. Earth Negotiations Bulletin. (2014). Summary of the Lima Climate Change Conference: 1-14 December 2014. International Institute for Sustainable Development. Retrieved from http:// www.iisd.ca/climate/cop20/enb/.

10. Egenhofer, C., \& Georgiev, A. (2009). The Copenhagen Accord a first stab at deciphering the implications for the EU. Brussels: CEPS. Retrieved from http://www.ceps.eu/.

11. Earth Negotiations Bulletin. (2012). Summary of the Doha Climate Change Conference. International Institute for Sustainable Development. Retrieved from http://www.iisd.ca/climate/ cop18/enb/. 
12. Fridahl, M., \& Linnér, B. (2015). Perspectives on the Green Climate Fund: possible compromises on capitalization and balanced allocation. Climate and Development, 8(2), 105-109. https:// doi.org/10.1080/17565529.2015.1040368.

13. Hampton, R. (2014). Attendance Report from United Nations Climate Change Conference Warsaw 2013: Conference of the Kyoto Agreement Parties (COP19). Melbourne: Forest \& Wood Products Australia Limited.

14. Hultman, N., \& Langley, C. (2013). Climate Change Negotiations in Warsaw Result in a Timeline for Agreement in 2015. The Brookings Institution. Retrieved from https://www.brookings. edu/blog/up-front/2013/11/27/climate-change-negotiations-in-warsaw-result.

15. International Institute for Sustainable Development. (2009). A Brief Analysis of the Copenhagen Climate Change Conference.

16. Intro to Cancun Agreements | UNFCCC. (2019). Retrieved 18 September 2019, from https:// unfccc.int/process/conferences/the-big-picture/milestones/the-cancun agreements.

17. International Institute for Sustainable Development. (2013). Summary of the Warsaw Climate Change Conference: 11-23 November 2013. Retrieved from http://www.iisd.ca/climate/cop19/ enb/.

18. Kulovesi, K. (2012). A new chapter in the UN climate change negotiations? First steps under the Durban Platform for Enhanced Action. Climate Law, 3(2), 181-189. https://doi.org/10.1163/ cl-2012-062.

19. Key outcomes of the Lima Climate Change Conference (COP20) | Sustainability for all. (2015). Retrieved 24 June 2015, from https://www.activesustainability.com/opinion/5-key-outcomesof-the-lima-climate-change-conference-cop20/.

20. Keohane, R. and Oppenheimer, M., 2016. Paris: Beyond the Climate Dead End through Pledge and Review? Politics and Governance, 4(3), pp.142-151.

21. Lal Pandey, C. (2014). The limits of climate change agreements: from past to present. International Journal of Climate Change Strategies and Management, 6(4), 376-390. https://doi. org/10.1108/ijccsm-03-2013-0026.

22. Marcu, A. (2012). Doha/COP 18: Gateway to a New Climate Change Agreement. Brussels: Centre for European Policy Studies. Retrieved from http://www.ceps.eu.

23. Moncel, R. (2012). Unconstructive Ambiguity in the Durban Climate Deal of COP 17 / CMP 7. Sustainable Development Law \& Policy, 12(2). Retrieved 26 July 2021, from https://digitalcommons.wcl.american.edu/cgi/viewcontent.cgi?referer=https://scholar.google.pl/\&httpsre$\operatorname{dir}=1 \&$ article $=1507 \&$ context $=$ sdlp

24. Niederberger, A., \& Kimble, M. (2011). MRV under the UN climate regime: paper tiger or catalyst for continual improvement? Greenhouse Gas Measurement and Management, 1(1), 47-54. https://doi.org/10.3763/ghgmm.2010.0009.

25. Scott, D., \& Becken, s. (2010). Adapting to climate change and climate policy: progress, problems and potentials. Journal of Sustainable Tourism, 18(3), 283-295. https://doi. org/10.1080/09669581003668540.

26. Summary and Analysis of the Durban Climate Change Conference, 28 November - 9 December 2011, Durban, South Africa. (2011). Retrieved 28 November 2011, from http://enb.iisd.org/ vol12/enb12534e.html.

27. Shockley, K., \& Boran, I. (2015). COP 20 Lima: The ethical dimension of climate negotiations on the way to Paris-Issues, challenges, prospects. Ethics, Policy \& Environment, 18(2), $117-$ 122. https://doi.org/10.1080/21550085.2015.1076564.

28. Tschakert, P. (2015). $1.5^{\circ} \mathrm{C}$ or $2^{\circ} \mathrm{C}$ : a conduit's view from the science-policy interface at COP 20 in Lima, Peru. Climate Change Responses, 2(1). https://doi.org/10.1186/s40665-015-0010-z. 
29. The Center for Climate and Energy Solutions. 2014. "Alongside the UNFCCC: Complementary Venues for Climate Action". United States: Stockholm Environment Institute.

30. The Center for Climate and Energy Solutions. (2011). Outcomes of the U.N. Climate Change Conference in Durban, South Africa.

\section{Further Reading}

1. Hudson, V., 2005. Foreign Policy Analysis: Actor-Specific Theory and the Ground of International Relations. Foreign Policy Analysis, 1(1), pp.1-30.

2. Heal, G. and Millner, A., 2014. Reflections. Review of Environmental Economics and Policy, 8(1), pp.120-137.

3. Onencan, A. and Van de Walle, B., 2018. From Paris Agreement to Action: Enhancing Climate Change Familiarity and Situation Awareness. Sustainability, 10(6), p.1929.

4. Maljean-Dubois, S., 2016. The Paris Agreement: A New Step in the Gradual Evolution of Differential Treatment in the Climate Regime?. Review of European, Comparative \& International Environmental Law, 25(2), pp.151-160.

5. Lawrence, M. and Schäfer, S., 2019. Promises and perils of the Paris Agreement. Science, 364(6443), pp.829-830. 